NBER WORKING PAPER SERIES

\title{
ESTIMATING THE PRODUCTIVITY SELECTION AND TECHNOLOGY SPILLOVER EFFECTS OF IMPORTS
}

\author{
Ram C. Acharya \\ Wolfgang Keller \\ Working Paper 14079 \\ http://www.nber.org/papers/w14079
NATIONAL BUREAU OF ECONOMIC RESEARCH
1050 Massachusetts Avenue
Cambridge, MA 02138 \\ June 2008
}

We are grateful to Jan DeLoecker, Ann Harrison, Margaret McMillan, Gianmarco Ottaviano, Carol Shiue, Catherine Wolfram, and Stephen Yeaple, as well as seminar audiences at the European Central Bank and UC Berkeley (Haas) for comments. Thanks also to Ray Fisman, Mark Roberts, and Virginia Sarria-Allende who helped with the data. Views expressed in the paper are those of the authors and do not necessarily reflect those of Industry Canada, or the National Bureau of Economic Research.

NBER working papers are circulated for discussion and comment purposes. They have not been peerreviewed or been subject to the review by the NBER Board of Directors that accompanies official NBER publications.

(C) 2008 by Ram C. Acharya and Wolfgang Keller. All rights reserved. Short sections of text, not to exceed two paragraphs, may be quoted without explicit permission provided that full credit, including (C) notice, is given to the source. 
Estimating the Productivity Selection and Technology Spillover Effects of Imports

Ram C. Acharya and Wolfgang Keller

NBER Working Paper No. 14079

June 2008, Revised October 2008

JEL No. F1,F2,O3,O33

\begin{abstract}
$\underline{\text { ABSTRACT }}$
Economists emphasize two channels through which import liberalization affects productivity, one operating between and the other within firms. According to the former, import competition triggers market share reallocations between domestic firms with different technological capabilities (selection). At the same time, imports can also improve firms' technologies through learning externalities (spillovers). We present evidence for a sample of industrialized countries over the period 1973 to 2002. First, in the long run, import liberalization lowers productivity in domestic industries through selection. This finding confirms the prediction of models with firm heterogeneity, including Melitz and Ottaviano (2008), in which unilateral liberalization lowers the profits of domestic relative to foreign exporters. Second, if imports involve advanced foreign technologies, liberalization also generates technological learning that can on net raise domestic productivity. Third, for short time horizons of up to three years, a surge in imports typically raises domestic productivity. Because the number of firms at home and abroad does not change much in the short-run, new competition from foreign firms has a pro-competitive effect. We also find that high entry barriers, especially regulation, slow down the process of market share reallocation between firms. Over- all, the results support models in which trade triggers both substantial selection and technological learning.
\end{abstract}

Ram C. Acharya

Industry Canada

10-East, 235 Queen Street

Ottawa, Ontario

Canada K1A 0H5

Acharya.Ram@ic.gc.ca

Wolfgang Keller

Department of Economics

University of Colorado at Boulder

Boulder, CO 80309-0256

and NBER

Wolfgang.Keller@colorado.edu 


\section{Introduction}

The recent growth of international trade has made for a much more integrated world. Many observers hold that trade contributes to the flow of ideas across borders because a major part of imports are new products. ${ }^{1}$ These innovations positively affect productivity if they trigger domestic technological learning within firms. Importing high-technology intermediate goods may also generate learning spillovers. How important, for example, were the United States intermediate imports of the emerging Irish computer industry for the recent productivity transformation of Ireland? ${ }^{2}$

International trade also changes the intensity of domestic competition and leads to productivity selection through the reallocation of market shares between firms that differ in their productivity (Melitz 2003). If trade barriers to a foreign market fall, this improves the relative profitability of high-productivity firms, since low-productivity firms tend to sell only domestically. Weak firms exit and market shares are reallocated to high-productivity firms, which raises average productivity (positive selection). At the same time, this makes it more difficult for firms of the liberalizing country-and specifically its relatively strong firms, the potential exporters-to compete abroad. In the liberalizing country, thus, the profits for the relatively productive firms decline, market shares shift to less productive firms, and relatively weak firms start operating. As a result, import liberalization leads to lower industry productivity (negative selection) in the liberalizing country. ${ }^{3}$

\footnotetext{
${ }^{1}$ This has been documented recently by Broda and Weinstein (2006).

${ }^{2}$ An overview of the literature on international technology diffusion is presented in Keller (2004).

${ }^{3}$ The seminal work by Melitz (2003) analyzes multilateral liberalization. Unilateral liberalization in a model with variable mark-ups is examined in Melitz and Ottaviano (2008); these authors show in addition that trade liberalization has a pro-competitive, productivity-raising impact in the short-run. Important
} 
While both the within and the between firm channel has been emphasized in recent work, relatively little is known on how the joint impact of selection and spillovers from imports liberalization shapes the location decisions of firms and the size of industries. This question is central for welfare analysis. For one, technology spillovers have a positive effect while the welfare effect through productivity selection can either be positive or negative. Consequently, openness more likely improves welfare if spillovers are relatively strong. ${ }^{4}$ Moreover, policy makers need to know how productivity selection across firms works in order to adopt sound policies towards firm entry and exit.

We present evidence for a sample of industrialized countries over the period 1973 to 2002. First, import liberalization lowers domestic productivity in the long-run, a finding which is consistent with recent models of firm heterogeneity because unilateral liberalization lowers the profits of domestic versus foreign exporters. Second, if imports are relatively technologyintensive, liberalization also generates technological learning that can on net raise domestic productivity. We also study the impact of entry and exit on the productivity consequences of import liberalization. In the short run of up to three years, there are productivity gains in the liberalizing country. In addition, the selection effect is muted when firm turnover is low or entry regulation is high. Overall, the results support models in which trade triggers both substantial selection and technological learning.

What is the evidence on firm selection and spillovers recently? Empirical work has

extensions of Melitz (2003) include Demidova (2006) and Falvey, Greenaway, and Yu (2006). Earlier papers showing that unilateral trade liberalization in the presence of free entry can lower welfare by shifting firms from the domestic country to foreign countries include Horstmann and Markusen (1986).

${ }^{4} \mathrm{~A}$ case where trade liberalization with heterogeneous firms and no technology spillovers leads to lower welfare is discussed in Demidova (2006). 
emphasized that increased openness can generate changes in competition and market share reallocations that add up to substantial domestic productivity improvements (Pavcnik 2002). At the same time, some studies point to a negative, not positive selection effect from increased openness. In their study of foreign direct investment (FDI) into Venezuela, for example, Aitken and Harrison (1999) demonstrate that FDI has lowered productivity among domestic plants, with one possible explanation being that foreign firms hire away the best workers. As for technology spillovers, Keller (2002) and others have shown that imports generate benefits from foreign R\&D investments. Moreover, Griffith, Harrison, and van Reenen (2006) find evidence for technology spillovers through outward FDI. And while the pioneering work found little evidence for learning from exporting (Bernard and Jensen 1999, Clerides, Lach, and Tybout 1998), the evidence is stronger in some more recent papers (van Biesebroeck 2005, De Loecker 2007). Indeed, surveys of the evidence on productivity gains from trade in micro studies conclude that foreign competition often improves intra-plant efficiency, citing technology spillovers as a possible explanation (Tybout 2003).

These findings notwithstanding, to the best of our knowledge there is no research that quantifies the relative importance of the competition and learning impact of imports in a single framework. This paper combines the broad coverage and focus on technology investments in industry studies with firm-level statistics, specifically the typical size of firms across industries. The analysis encompasses about $85 \%$ of all manufacturing R\&D in the world. Moreover, we observe R\&D spending by both importers and exporters. This information on technology investments is crucial; without it, learning externalities will likely be missed. Studies of the effects of trade liberalization using micro data rarely employ rich information 
on technology investments, in part because the information is unavailable: the micro unit is often a plant, whereas R\&D decisions are made at the firm level.

The relatively large cross-sectional dimension of this study, twenty-two industries in sixteen countries, means that our findings are representative for many economies. Another advantage of our setting is that we trace out productivity and imports dynamics over three decades (years 1973 to 2002), because it allows to distinguish the long-run from the shortrun effects of imports liberalization. The detailed information technology investments for a broad sample comes at the cost of having no micro-level information on market shares. At the same time, we have data on the number of firms by industry. This reflects net entry rates (entry minus exit), picking up an extensive margin in the firm selection process. Moreover, information on the number of firms is used to compute average firm size. In models of productivity heterogeneity, productivity and average firm size typically move together, because the reason why some firms are small (large) in the first place is that they have low (high) productivity. Therefore, changes in average firm size triggered by imports gives an alternative measure of selection that can be studied.

This research also contributes to what we know about the churning of firms across industries and countries. It is well-known that churning across industries varies considerably in terms of entry and exit barriers (Dunne, Roberts, and Samuelson 1988). Moreover, recent work has shown that differences in entry regulation across countries plays an important role in explaining countries' growth experiences (Djankov, La Porta, Lopez-de-Silanes, and Shleifer 2002)). We highlight one major reason for firm churning, namely increases in foreign competition through imports. Consistent with recent work, we show that variation in nat- 
ural and policy-induced entry barriers are important in explaining productivity outcomes.

In the present context, high entry barriers slow down the exit of relatively productive, and the entry of relatively unproductive domestic firms, thereby raising productivity. Of course, as this research emphasizes, the overall welfare impact of entry regulation will depend on its effect on both selection and technological learning.

Related to our work is the paper by Chen, Imbs, and Scott (2006). These authors extend the Melitz and Ottaviano (2008) model to study trade-induced changes in prices and mark-ups with data on European industries. Chen, Imbs, and Schott's work addresses the competition effects of trade, both short-run and long-run, whereas the present paper focuses on long-run predictions in a framework where imports can affect both the degree of competition and technological learning. ${ }^{5}$

In the remainder of the paper, we first introduce the data in section 2 before outlining the estimation approach in section 3. This is followed by the empirical results (section 4). Section 5 provides a concluding discussion.

\section{Data}

Since technical discoveries tend to emerge in an uneven way across industries, we study trade and productivity at the industry-level. During the 1990s, most of the technological break-

\footnotetext{
${ }^{5}$ Some parallels also exist with work by Combes, Duranton, Gobillon, Puga, and Roux (2007), who analyze firm selection and agglomeration effects on productivity. This paper differs, first, in that our focus is on technology spillovers, not agglomeration economies. Second, firm selection and spillovers have qualitatively different productivity implications in our setting, namely negative for unilateral trade liberalization, and positive for technological learning. In contrast, Combes, Duranton, Gobillon, Puga, and Roux examine the effect of larger market size, which raises productivity, albeit differentially, via both selection and agglomeration.
} 
throughs came in the information and communication technology (ICT) industries. While the ICT innovations were important even at the manufacturing or the economy wide-level, for us a sufficient degree of industry detail is crucial. This paper examines manufacturing disaggregated into twenty-two industries. ${ }^{6}$ The classification allows to isolate key sectors such as computers and communication equipment technologies.

The analysis covers manufacturing activity in seventeen industrialized countries. ${ }^{7}$ Throughout the three decades of our sample (the years 1973 to 2002), these countries, located in four continents, accounted for a large portion of the world's manufacturing activity. The technology trends we study are truly global in the sense that during these three decades the sample encompasses more than $85 \%$ of the world's manufacturing R\&D investments.

Internationally comparable figures on employment, output, and sectoral prices come from Groningen Growth and Development Centre (GGDC) database (van Ark et al. 2005) for the years 1979-2002. The GGDC project represents an extension of the OECD's STAN database in that output and price measures for sectors that were key drivers of technological change are separately included. We have combined this with information on employment, output and sectoral prices for 1973-78 from the OECD's STAN database (OECD 2008a). ${ }^{8}$ Also from the STAN database comes the information on physical capital investment. Figures on R\&D spending are from the ANBERD database (OECD 2008b), and information on bilateral trade at the industry level comes from the BTD database (OECD 2008c). ${ }^{9}$

\footnotetext{
${ }^{6}$ They are listed in Table 6.

${ }^{7}$ The countries are listed in Table 3 .

${ }^{8}$ More details on the sources and construction of this data is given in Acharya and Keller (2007).

${ }^{9}$ The output measure is the value added produced in an industry. Labor services are measured in terms of the number of workers. Information on physical capital investment has been employed to construct capital stocks, and similarly, we have calculated R\&D stocks based on data on R\&D spending.
} 
This provides a rich basis for the empirical work in that the sample goes beyond earlier studies in terms of variation in the country, industry, and time dimensions. In addition, we have obtained figures on output and the number of establishments in order to study firm size dynamics. This information comes from data collected by the United Nations Industrial Development Organization (UNIDO) and prepared by Nicita and Olarreaga (2006). It yields a measure of average firm size that can shed additional light on market share reallocations analyzed by heterogeneous firm models. ${ }^{10}$ The UNIDO data provides average firm size information for the years 1981 to 2002 at the three-digit ISIC level. ${ }^{11}$

This study also employs measures on firm entry and exit from the following sources. First, there is information on the regulation of entry from the World Bank Investment Climate Surveys, as reported in Djankov, La Porta, Lopez-de-Silanes, and Shleifer (2002). Figure 1 shows the number of procedures that need to be completed to start a business across countries, with high numbers indicating relatively strong entry barriers. In our sample, this varies from sixteen in Italy to two in Australia and Canada, while the number for the U.S., with four, is also relatively low. The dynamics of firm entry and exit also varies due to industry-specific characteristics. We employ data on U.S. gross turnover (equal to firm entry plus firm exit divided by number of firms) derived from Dunne, Roberts, and Samuelson (1988). Since for all industries, policy barriers in the U.S. are relatively low, the variation

\footnotetext{
${ }^{10}$ For the purposes of this paper, we use the terms establishment and firm synonymously. To the best of our knowledge, cross-country, cross-industry data for a broad sample that allows this distinction at the empirical level does not exist. In any case, our definition of average size, industry output divided by the number of establishments, corresponds to the notion of a firm in Melitz (2003) and others.

${ }^{11}$ For a small number of industries, this is more aggregated than the information on $\mathrm{R} \& \mathrm{D}$ and trade volumes, and in these cases we apply the three-digit average firm size figures to all sectors that belong to this three-digit ISIC industry. See Table A1 for details.
} 
in gross turnover can be viewed as picking up natural, or not policy-induced, barriers to entry and exit. For a limited set of countries, it has recently become possible to estimate comparable turnover rates by country and industry (Bartelsman, Haltiwanger, and Scarpetta 2007). Figure 2 shows this data for Italy and the UK. As expected from the relatively high entry barriers in Italy across the board (Figure 1), turnover rates in Italy are lower for each industry. At the same time, Figure 2 confirms that the industry ordering of turnover is similar across countries.

Table 1 presents summary statistics for some key variables. There are typically about 10,000 observations, which reflects the fact that there are only a few missing observations. ${ }^{12}$ The exception is information on average firm size, which is available for a somewhat smaller number of years and countries. Both R\&D and productivity have grown over these three decades, with $R \& D$ growth generally outpacing productivity growth (Table 2). At the same time, the rate of total factor productivity (TFP) growth, of around 3\% per year, is itself quite high by historic standards. The average growth of imports from the U.S. is almost twice as large as the growth of U.S. R\&D over this period. In terms of our study, the increased product market integration helps to identify any productivity selection and spillovers that imports might initiate.

Tables 3 and 4 provide some initial information on the sample variation across countries. Over these three decades, the United States has been the productivity leader, with the highest average productivity level, and Canada is a close second in the productivity ranking (Table 3). Productivity growth was highest in South Korea, in part because it is still catching-up

\footnotetext{
${ }^{12}$ With 17 countries, 22 industries, and 30 years, there are 11,220 possible observations.
} 
to the more advanced countries. The country with the second-highest productivity growth rate is Finland, which may be related to high productivity growth in industries such as communication equipment.

The United States is the largest creator of new technology in the world, measured by its R\&D spending (Table 4). This is the reason for our focus on selection and spillovers associated with U.S. R\&D and imports. The importance of U.S. imports relative to domestic production becomes clear from Table 5. The U.S.' important role for Canada is well known, with U.S. imports being almost three-fourths of domestic value added on average in the 1990s. But also in Ireland and Australia, U.S. imports are large relative to the domestic industry size, and even in the large OECD countries such as Germany or the U.K., U.S. imports amount to between $3 \%$ and $15 \%$ of domestic industry size.

Tables 6 and 7 show the variation across industries. Most technology creation as measured by R\&D occurs in the aircraft, motor vehicles industries, and communications equipment industries, but also computers, chemicals, and pharmaceuticals account for a relatively large share of total R\&D (Table 6). While this is based on $R \& D$ in the United States, the distribution of R\&D across industries in other OECD countries is in fact quite similar. Finally, Table 7 looks at the importance of U.S. imports by industry, and shows that the relative importance of imports from the U.S. is highest for the aircraft and computer industries, followed by instruments and communication equipment.

In the following section we describe the estimation approach. 


\section{Estimation}

This paper analyzes productivity dynamics by extending the R\&D-and-production function framework pioneered by Griliches (1979) and others to include imports. Earlier work has yielded a positive relationship between R\&D expenditures and total factor productivity. R\&D spending in one firm may raise the productivity of other firms if there are technological externalities, or spillovers. These may also be important at the industry- or country-level.

When firms with different productivity levels compete, market share reallocations are an independent reason for changes in industry productivity. In the context of international trade, an increase in imports is indicative of a relatively less profitable competitive position of domestic firms. With free entry, this lowers average productivity at home. One reason for a surge in imports is often that the domestic market has become more accessible in terms of trade costs (e.g. tariffs, non-tariff barriers, or transport costs have fallen). Another reason for increased imports might be that an increase in $R \& D$ spending has made foreign firms relatively more competitive. If so, this reallocates export opportunities away from domestic and towards foreign firms. The reduction of expected profits for domestic firms will shift domestic market shares from high- to low-productivity firms, thereby lowering industry productivity. ${ }^{13}$

Thus, an increase in imports and foreign $\mathrm{R} \& \mathrm{D}$ may lower domestic productivity through selection, and it may raise domestic productivity to the extent that there are significant tech-

\footnotetext{
${ }^{13}$ See Melitz and Ottaviano (2008), Demidova (2006) and Falvey, Greenaway, and Yu (2006) for details.
} 
nology spillovers. To estimate their relative importance, consider the following framework:

$$
t f p_{c i t}=\beta_{d^{\prime}} r_{c i t}^{d}+\sum_{c^{\prime}} \beta_{c^{\prime}} r_{c^{\prime} i t}^{f}+\sum_{c^{\prime}} \beta_{c^{\prime}} m_{c c^{\prime} i t}+\varepsilon_{c i t}
$$

where $t f p_{c i t}$ is a measure of total factor productivity in industry $i$ and year $t$ of country $c$, with $i=1, \ldots, 22, c=1, \ldots, 16$, and $t=1973, \ldots, 2002$. Since the assumption of constant returns to scale is not rejected, we impose it and construct TFP as $t f p_{c i t}=y_{c i t}-\alpha l_{c i t}-(1-\alpha) k_{c i t}$, where $y_{c i t}$ is value added, $l_{c i t}$ employment (number of workers), and $k_{c i t}$ is the capital stock, all in logs. We choose $\alpha=0.72$, which is equal to the median labor share in the sample. ${ }^{14}$ The variables $r_{c i t}^{d}$ and $r_{c^{\prime} i t}^{f}$ in equation (1) are domestic and foreign R\&D (in logs), and $m_{c c^{\prime} i t}$ is the $\log$ imports of country $c$ 's industry $i$ from the same industry in country $c^{\prime}$ in year $t$. The variable $\varepsilon_{c i t}$ is an error term that will be defined below.

In principle, we could study the relationships between all OECD countries symmetrically. However, relatively small countries such as Belgium or Denmark are unlikely to have a comparable impact on other OECD countries as have larger countries. As shown above, the United States, in particular, is relatively large in terms of $R \& D$ and exports to all other sample countries, and for the most part we focus on imports- and R\&D effects of the U.S. in 16 other OECD countries. Equation (1) is specialized to

$$
t f p_{c i t}=\beta_{0}+\beta_{d} r_{c i t}^{d}+\beta_{U} r_{U i t}^{f}+\beta_{m} m_{U c i t}+\beta_{J} r_{J i t}^{f}+\beta_{G} r_{G i t}^{f}+\varepsilon_{c i t},
$$

\footnotetext{
${ }^{14}$ Acharya and Keller (2007) obtain production function elasticity estimates for these industries, showing that the labor (capital) elasticity is very close to the labor (one minus the labor) share. We have also employed alternative TFP measures that incorporate information on industry-specific factor shares; as Table A3 shows, this leads to similar results.
} 
where $r_{U i t}^{f}, r_{J i t}^{f}$ and $r_{\text {Git }}^{f}$ are log R\&D stocks in the U.S., Japan, and Germany, and $m_{U c i t}$ is log imports from the United States. Japan and Germany are the second- and thirdlargest countries in terms of $R \& D$ in the sample, and they may have significant effects on productivity independent of U.S. R\&D and exports. ${ }^{15}$

In order to better assess the relative importance of selection and technology spillovers, we also add the interaction of imports with $R \& D$

$$
t f p_{c i t}=\Psi+\beta_{U} r_{U i t}^{f}+\beta_{m} m_{U c i t}+\beta_{e}\left[m_{U c i t} \times r_{U i t}^{f}\right]+\varepsilon_{c i t}
$$

where $\Psi=\beta_{0}+\beta_{d} r_{c i t}^{d}+\beta_{J} r_{J i t}^{f}+\beta_{G} r_{G i t}^{f}$. The parameter $\beta_{e}$ indicates whether the productivity impact of U.S. imports varies with the technology embodied in these imports, which we capture by multiplying U.S. imports with U.S. R\&D.

Two generic issues in estimating equation (3) are possible omitted variables and endogeneity. To address these, we employ two different estimators: (1) fixed effects ('within') estimation and (2) dynamic instrumental variable (IV) estimation. In the former, the error term is specified as

$$
\varepsilon_{c i t}^{w}=\mu_{c i}+\eta_{t}+u_{c i t}
$$

where $\mu_{c i}$ are deterministic fixed effects for each country-by-industry combination, $\eta_{t}$ is a fixed effect for each year, and $u_{c i t}$ is a mean-zero but possibly heteroskedastic disturbance. The $\mu_{c i}$ fixed effects will control for any heterogeneity across industries that is omitted from

\footnotetext{
${ }^{15}$ Adding R\&D variables of other major countries (e.g., France, the U.K., Canada, or Italy) does not affect our key results.
} 
(3) and constant over time.

Results using the IV estimator proposed by Arellano, Blundell, Bond, and others are also presented (Arellano and Bond 1991, Blundell and Bond 2000). In that case, the regression error is given by

$$
\begin{gathered}
\varepsilon_{c i t}^{b}=\lambda_{c}+\varsigma_{i}+\eta_{t}+\nu_{c i t} \\
\nu_{c i t}=\rho \nu_{c i t-1}+u_{c i t}
\end{gathered}
$$

Here, $\lambda_{c}, \varsigma_{i}$, and $\eta_{t}$ are deterministic fixed effects for each country, industry, and year, respectively. The random shock $\nu_{\text {cit }}$ changes over time following an $\mathrm{AR}(1)$. This approach yields moment conditions for combining equations in the variables' levels with equations in the variables' differences for a so-called System GMM approach. In both sets of equations, one essentially uses lagged values to construct instrumental variables for current variables.

An advantage of the Systems GMM estimator is that it deals with possible endogeneity. The cost is in the form of additional assumptions and added complexity, as well as a smaller sample due to the lags needed to construct the instruments. In this case, we find qualitatively similar results using either estimation method. ${ }^{16}$

\footnotetext{
${ }^{16}$ We have also considered the Olley and Pakes (1996) estimator, and found that the results are quite similar in this context; see van Biesebroeck (2004) who analyzes the robustness of several related estimators more generally.
} 


\section{Estimation results}

\subsection{Productivity selection and spillovers from imports}

This section presents our empirical results. We begin with fixed-effects estimates in Table 8 before turning to IV results in Table 9 . The first column of Table 8 gives results for the following specification:

$$
t f p_{c i t}=\mu_{c i}+\eta_{t}+\beta_{U} r_{U i t}^{f}+\beta_{d} r_{c i t}^{d}+\beta_{J} r_{J i t}^{f}+\beta_{G} r_{G i t}^{f}+u_{c i t}
$$

where $\mu_{c i}$ and $\eta_{t}$ are fixed effects that are treated as parameters. The sample consists of the years 1973 to 2002 , though the sample is somewhat smaller because all independent variables are lagged by two years in order to reduce endogeneity problems. ${ }^{17}$ The domestic R\&D elasticity is 0.11, and those for U.S., Japan, and Germany are about 0.24, 0.21, and 0.07, respectively; these figures are in line with what earlier studies found (see Griliches 1995). Replacing the U.S. R\&D variable with imports from the U.S., the import coefficient is negative (column 2).

When both U.S. imports and R\&D are included together with their interaction $m_{U c i t} \times$ $r_{U i t}^{f}$, it is the latter that is estimated to have a positive effect on productivity; the direct U.S. imports and R\&D impact actually lower domestic productivity (column 4). This is consistent with substantial productivity selection through the product market impacts of foreign R\&D and imports, as predicted by heterogeneous firm models. In addition, the

\footnotetext{
${ }^{17}$ Since we want to estimate the effects from U.S. imports and R\&D, we also eliminate the 22 U.S. industries from the sample; it consists of the remaining 16 OECD countries, times 22 industries.
} 
positive coefficient on the imports-R\&D interaction indicates that if the imports from the U.S. are highly technology-intensive, this generates technological externalities that raise productivity in the importing country.

The IV results are presented in Table 9. The first specification is comparable to column (3) in Table 1, except that the IV regression has about 1,000 fewer observations due to lags needed to construct instruments. According to both the fixed effects and the IV results, U.S. R\&D raises domestic productivity while imports from the U.S. tend to lower it. We also report Hansen's J from the test of overidentifying restrictions. The p-value of 0.655 indicates that one cannot reject the null hypothesis that the instruments as a set are valid. ${ }^{18}$ Adding the imports-R\&D interaction yields a positive coefficient, as before (Table 9, column 2). Tables 8 and 9 also report the $90 \%$ confidence interval for the U.S. imports and U.S. R\&D impacts. While the mean imports effect is close to zero (-0.02 for the fixed effects, and -0.01 for the IV), the confidence interval covers both sizable positive and negative elasticities, ranging at least from -0.09 to 0.06 . Overall, the fixed effects and IV estimators lead to quite similar results.

An important question is whether our the estimated US R\&D- and imports effects are truly reflecting productivity selection as emphasized in recent firm heterogeneity models, or indeed something else. To address this issue, we utilize information on the number of firms by industry and analyze the dynamics of average firm size and the number of firms.

As noted above, in the typical firm heterogeneity model, productivity and firm size move together. This means that the average firms size in an industry should be affected in the

\footnotetext{
${ }^{18}$ The set of instruments is given at the bottom of Table 10.
} 
same way as productivity by U.S. R\&D and U.S. imports. Table 10 shows regressions of the log of average firms size as an alternative dependent variable to TFP. We also employ the number of firms in an industry, which directly reflects (net) entry and exit. Unilateral import liberalization leads to a lower threshold that a firm's productivity has to surpass in order to break even. Thus, the lower industry productivity through unilateral import liberalization should be associated with an increase in the number of firms. We examine this in Table 10 by employing the (log) number of firms as an alternative dependent variable. TFP specifications analogous to those in Table 8 for the years 1981-2002, for which the number of firm data is available, are shown as well.

We see, first, that U.S. R\&D has a positive impact on productivity and firm size, while it has a negative effect on the number of firms. The former provides additional support that U.S. R\&D generates technological learning, and the fact that productivity and average firm size are affected in the same way is consistent with recent heterogeneous firm models. The negative impact of U.S. R\&D on the number of firms in (3) and (6) suggests that relatively productive firms tend to benefit more from U.S. R\&D than weaker firms. Second, U.S. imports affect productivity and firm size qualitatively in the same way. High-technology imports raise firm size, low-tech imports reduce firms size, and the average effect is close to zero. From specification (6), the impact of U.S. imports on the number of firms is the reverse: the number of firms goes up if the imports are low-technology, and the number of firms falls if imports are high-technology. The finding suggests that a surge of imports unaccompanied by technological learning leads to the net entry of relatively weak domestic firms. It provides strong evidence that we estimate the long run heterogeneous-firm selection effect, since in 
the typical homogenous-firm model a surge in imports would displace domestic firms, not add to their number.

How large are the selection and spillover effects quantitatively? The elasticity of TFP with respect to U.S. imports and U.S. R\&D is reported in Tables 8 and 9 at the bottom. The average imports elasticity appears to be negative but close to zero; for these specifications, the values range from $-3.7 \%$ to $-1.0 \%$. The impact of U.S. imports on domestic productivity varies strongly, however, depending on how technology intensive imports are: for the fixed effects specification (4) in Table 8, the value for the 5th percentile of the import elasticity (low-technology imports) is -0.09 , while at the 95th percentile (high-technology imports), it is 0.06 . respectively. Selection is generally quite important: about two thirds of all industries experience lower productivity as a consequence of an increase in U.S. imports (specification (4) in Table 8).

In contrast to imports, the average U.S. R\&D elasticity is positive, at about $25 \%$. From the point of view of the importer, the amount of U.S. R\&D determines whether imports from the U.S. lead to higher or lower domestic productivity. For example, a change of U.S. R\&D spending from the 25 th to the 75 th percentile is associated with a 6.4 percentage points increase in the imports elasticity (for (4), Table 8). With an average imports elasticity of $-2.0 \%$, it is clear that how technology-intensive imports are is critical for the productivity consequences in the liberalizing economy. Overall, the results are consistent with models in which trade generates both major selection processes and technology spillovers.

The robustness of the estimates has been analyzed. We have, first, asked whether the imports and R\&D of other major countries such as Japan and Germany also generate a 
mix of selection and spillover effects, or whether these are specific phenomena for the United States. ${ }^{19}$ Second, the productivity variable is based on the same labor- and capital elasticities for all industries. In Table A3, we report results for an alternative TFP variable, which is based on input elasticities that vary by industry. ${ }^{20}$ Both sets of results are similar to those discussed above.

The following section studies how firm entry and exit affect spillover and selection effects.

\subsection{Extensive margin-dynamics, selection, and spillovers}

Our analysis of how firm dynamics shape selection due to imports begins by employing measures on the gross turnover of firms compiled by Bartelsmann, Haltiwanger, and Scarpetta (2007). This information varies both by industry and by country, which is attractive because firm dynamics may vary importantly across both dimensions (recall Figure 2). ${ }^{21}$ We define an indicator variable $I_{c i}^{L T}$ which is equal to one if gross turnover in a particular industry is in the lowest quartile of all industries' turnover. Turnover may be low in these industries both due to certain industry characteristics such as high set-up costs and heavy entry and exit regulation. As a result, such industries are characterized by relatively low entry and exit rates, which one would expect to slow down the firm selection process.

\footnotetext{
${ }^{19}$ In Table A2, we compare the results for the U.S. with those for Japan and Germany. Table A2's column (1) repeats the earlier results for the U.S. from Table 8, (4), while columns (2) and (3) report analogous results for Japan and Germany, respectively.

${ }^{20}$ The alternative TFP indices use $\tilde{\alpha}_{i}$ as labor's share, which is the median labor share for each industry $i$, together with the assumption of CRS. Most of the variation in the labor shares is in the industry, not country or time dimension.

${ }^{21}$ There is country-specific data for eight of our sample countries; for the others, we employ the average values. The turnover values are averages from annual data, typically for the period 1984-98, see Bartelsman, Haltiwanger, and Scarpetta (2007), Table 1.
} 
In Table 11, we present evidence on this by examining whether the impact of US R\&D and imports is significantly different in low-turnover industries. Column (1) reports again the results of (3), Table 8 as a benchmark. Column (2) adds the domestic R\&D-low turnover interaction, which is not significant. Columns (3) and (4) indicate that the productivity benefits of US R\&D are about one third lower in low turnover-industries. This suggests that there is a reduced level of within-firm technological learning in industries that are among the least vibrant in terms of firm entry and exit.

The US imports-low turnover interaction in column (4) enters with a positive sign. This says that relatively low firm turnover is associated with smaller productivity losses due to selection triggered by a surge in imports. Interestingly, the interaction coefficient is equal to 0.048 , which is the same absolute value as the imports selection coefficient (at -0.048). Thus, if firm turnover is low, this can completely bring to a halt the impact from selection.

One concern is that country-specific turnover rates may be endogenous in these regressions. While it is unlikely that endogeneity plays a major role since we do not employ annual information on turnover, we address this issue further by using information on gross turnover in US industries throughout, instead of the country-specific turnover data. The results are shown in column (5) of Table 11. The impact of firm dynamics on spillovers and selection is unchanged: U.S. R\&D generates a lower benefit in low-turnover industries, and U.S. imports trigger a smaller productivity loss in low-turnover industries. This suggests that the results with country-specific turnover information are not importantly driven by endogeneity. ${ }^{22}$

\footnotetext{
${ }^{22}$ This is also consistent with Dunne and Roberts (1991) who argue that variation in turnover across industries in the US is likely going to be similar to the industry variation in other countries. Note, however, that the domestic R\&D impact in low turnover industries is larger when US- compared to when countryspecific turnover data is employed.
} 
Next, we examine the impact of policy-induced entry barriers. Let the indicator variable $I_{c}^{H R}$ be equal to one if the observation is in the highest quartile in terms of the numbers of procedures that need to be completed before a business can start operating, and zero otherwise. We expect that a high degree of regulation will lead to a relatively low rate of firm entry. Table 12 shows these results. First, consider the impact of domestic R\&D in a high-regulation environment. The domestic R\&D-high regulation interaction is first positive (specifications (1) and (2)), but it is negative in the full specification (3), suggesting that domestic $\mathrm{R} \& \mathrm{D}$ yields smaller productivity gains in a highly regulated environment (not significant at standard levels). Second, there is no major difference between regulated and not regulated industries in terms of their technology spillovers from U.S. R\&D (columns (2) and (3)). At the same time, the imports effect on productivity is significantly lower in highly regulated industries (column (3)). This is consistent with entry regulation being to some extent a shield against the negative impact of imports-induced long-run productivity selection.

The last column of Table 12 includes both the low turnover- and high regulation variables jointly, which allows to see whether they have independent effects. The productivity impact of a surge in US imports is reduced by both a high degree of regulation and a low level of firm turnover. In contrast, while technology spillovers from the U.S. are generally higher in high turnover industries-the U.S. R\&D-low turnover coefficient is negative-, there is no evidence that technology spillovers from the US are lower specifically due to high levels of regulation. Overall, we find that factors slowing down entry and exit can have a major influence on market share reallocations between firms with different productivities. 


\subsection{Selection over time}

In the light of these results, it is plausible that time is another determinant of the size of the selection effect: natural entry barriers and entry regulation should have its strongest impact in the short-run, when it is very costly to overcome these barriers. In the heterogeneous firm model of Melitz and Ottaviano (2008), for example, unilateral import liberalization has a positive impact on domestic productivity in the short-run, when the number of firms at home and abroad is given, and a negative impact in the long-run, when firm entry and exit has set in. More generally, the short-run response of industry productivity to additional import competition might be quite different from the long-run response.

To examine this empirically, we run a set of time-differenced regressions. Consider the following equation

$$
\Delta^{q}\left(t f p_{c i t}\right)=\gamma_{1} \Delta^{q}\left(r_{U i t}^{f}\right)+\gamma_{2} \Delta^{q}\left(m_{U c i t}\right)+\gamma X^{\prime}+v_{c i t}
$$

where $\Delta^{q}$ is the time-difference operator of length $q$, so that $q=1$ are one-year differences, $q=2$ are two-year differences, and so forth. We consider $q=1, . ., 10$, that is, one-year to ten-year differences. One-year differences estimate a relatively short-run impact, while a time horizon of one decade picks up a more long-run effect. As control variables, $X$, we include changes in own R\&D, Japanese, and German R\&D, as well as time fixed effects. ${ }^{23}$ Also

\footnotetext{
${ }^{23}$ We also restrict the sample period to the years 1983 to 2002 . Since the sample covers the years 1973 to 2002, 1983 is the first year for which we can form ten-year differences. This ensures that the results are not affected by the inclusion or exclusion of the early years in our sample.
} 
results for time-differenced regressions with the R\&D-Imports interaction will be shown:

$$
\Delta^{q}\left(t f p_{c i t}\right)=\gamma_{1} \Delta^{q}\left(r_{U i t}^{f}\right)+\gamma_{2} \Delta^{q}\left(m_{U c i t}\right)+\gamma_{3}\left[\Delta^{q}\left(r_{U i t}^{f}\right) \times \Delta^{q}\left(m_{U c i t}\right)\right]+\gamma X^{\prime}+v_{c i t} .
$$

Table 13 reports the estimates of $\gamma_{1}$ and $\gamma_{2}$ of equation (6) for different time horizons, and Figure 3 gives a graphical depiction of the average elasticities. ${ }^{24}$ The productivity effect of imports is significantly positive for a one- to three-year time horizon. For the four- to sixyear time horizons, the imports effect is close to zero, while for a seven-year or longer time horizon, the productivity impact of unilateral import liberalization is significantly negative. Also shown in Figure 3 are the average TFP effects of imports based on the interaction specification, equation (7), which are very similar. The fact that the imports effect almost monotonically declines as the time horizon becomes longer is exactly what one expects if productivity selection through firm entry and exit at home and abroad is evolving over time. $^{25}$ Moreover, the findings strikingly confirm the predictions of recent heterogeneous firm models such as Melitz and Ottaviano (2008). By contrast, the marginal effect of US R\&D on productivity varies relatively little for different time horizons.

To summarize, productivity selection from imports is moderated when firm turnover is low, entry regulation is high, and in general over short time horizons.

\footnotetext{
${ }^{24}$ As shown above, the impact of imports varies with their technology intensity.

${ }^{25}$ While small sample size precludes precise estimation for longer time differences, it appears that the imports effect does not change any further beyond about 13 years.
} 


\section{Conclusions}

Does importing affect domestic productivity through selection and technology spillovers? To answer this question, we analyzed the productivity dynamics in response to U.S. exports in several major countries. It is particularly revealing to look at changes triggered by US exports, both because the U.S. is an important and sometimes even dominant trade partner, and because the United States is the single most important source of technology creation in the world, accounting for about $40 \%$ of the world's R\&D spending. To examine the impact of imports, we study productivity dynamics at the industry-level. The analysis focuses on the productivity effects of imports through selection and technology spillovers. Admittedly, international product market competition need not take the form of trade, and productivity might be affected by factors other than selection and spillovers. However, these mechanisms are central to recent theoretical and empirical work, and they are much-emphasized in the policy discussion as well. Our empirical results strikingly demonstrate that selection and technology spillovers must figure prominently in any successful explanation according to which international trade affects productivity.

It would have been impossible to arrive at these results without extensive data. To this end, we constructed a unique database on manufacturing inputs, outputs, and international trade volumes for most of the industrialized world and a relatively long thirty-year sample period. The analysis includes sufficient detail to isolate major technology drivers such as the computer and communication equipment industries. This is combined with information on the typical firm's size to trace out market share reallocations in response to a surge in 
imports.

Our main conclusions are as follows: First, import liberalization lowers domestic productivity in the long-run through the selection effect. This confirms the prediction of recent models of firm heterogeneity because unilateral liberalization shifts profits from domestic to foreign exporters. Second, if imports are relatively technology-intensive, liberalization also generates technological learning that can on net raise domestic productivity. Third, we show that in the short-run of up to about three years, a surge in imports raises domestic productivity. Because the number of firms at home and abroad does not change much in the short-run, new competition from foreign firms has a pro-competitive effect. We also find that the selection effect is muted when firm turnover is low or entry regulation is high.

Overall, the results indicate that market share reallocations between firms in response to changes in foreign competition are important. Moreover, the evidence lines up very well with recent heterogeneous firm trade models such as Melitz and Ottaviano (2008). Specifically, we find that firm selection induced by imports liberalization raises domestic productivity in the short-run, and it reduces it in the long-run. The level of entry regulation matters for the extent that firm churning in response to import competition contributes to the overall change in productivity. This finding is consistent with an emphasis on firm dynamics as a key explanation for performance differences across countries. ${ }^{26}$

At the same time, the evidence shows that we need models in which imports lead to both selection and technology spillovers. The inclusion of both selection and spillovers matters more for long-run than short-run policy advice, since as we have seen in the short-run a surge

\footnotetext{
${ }^{26}$ See Bartelsman, Haltiwanger, and Scarpetta (2007) and Ahn (2000) for an overview.
} 
in imports yields productivity gains. In the long-run, the net impact of imports hinges on the relative size of the selection and the technology spillover effect. If new imports primarily amount to increased product market competition, the selection effect dominates and domestic productivity falls. In contrast, if imports are a significant source of new technology, this can outweigh the competition effect, leading to a long-run increase in domestic productivity. It is plausible that our results analogously apply to exports and foreign direct investment, although at this point this is a conjecture.

It is also important to ask why most studies to date tend to find that productivity rises with increased foreign competition, whereas our results are not as clear-cut in this respect. We can think of at least two reasons for this. First, this study has examined changes in import competition over roughly three decades. This sample period is substantially longer than what is typically considered in studies of the productivity effects of trade liberalization. We believe that the relatively long sample period is crucial for estimating the long-run selection effect of imports predicted by influential recent papers. At the same time, for relatively short time horizons, we find a pro-competitive effect from import liberalization. From this perspective, our results are not so much in conflict with existing results as that they add a new finding, on the long-run impact of import liberalization.

Another reason, not mutually exclusive, might be that in the presence of increased foreign competition in fact there is technology upgrading and learning taking place. ${ }^{27}$ While relatively few micro studies of trade liberalization employ data on technology investments, it

\footnotetext{
${ }^{27}$ There is evidence that firms make technology investments to prepare for more intensive competition, which by itself might lead to higher productivity. An example is Hallward-Driemeier, Iarossi, and Sokoloff (2002).
} 
is quite possible that unobserved simultaneous technology investments are affecting the observed productivity levels. ${ }^{28}$ Future research will have to analyze the importance of these and possibly other determinants of the impact of increased openness on domestic productivity and welfare.

\footnotetext{
${ }^{28}$ In this regard, the papers by Bustos (2007) and Verhoogen (2007) are noteworthy.
} 


\section{References}

[1] Acharya, R., and W. Keller (2007), "The Evolution of the World's Technology Frontier, 1973-2002", Industry Canada Working Paper \# 2007-03.

[2] Ahn, S. (2000), "Firm dynamics and productivity growth: a review of micro evidence from OECD countries", OECD Economics Department working paper \# 297.

[3] Aitken, B., and A. Harrison (1999), "Do Domestic Firms Benefit from DFI? Evidence from Venezuela", American Economic Review 89: 605-618.

[4] Arellano, M. and S. Bond (1991), "Some Tests of Specification for Panel Data: Monte Carlo Evidence and an Application to Employment Equations", Review of Economic Studies 58: 277-97.

[5] Bartelsman, E., J. Haltiwanger, and S. Scarpetta (2007), "Measuring and analyzing cross-country differences in firm dynamics", working paper, Free University Amsterdam, December.

[6] Bernard, A., and B. Jensen (1999), "Exceptional Exporter Performance: Cause, Effect, or Both?", Journal of International Economics 47: 1-25.

[7] Blundell, R., and S. Bond (2000), "GMM Estimation with Persistent Panel Data: An Application to Production Functions", Econometric Reviews 19: 321-340.

[8] Broda, C., and D. Weinstein (2006), "Globalization and the Gains from Variety", Quarterly Journal of Economics 121: 541-585. 
[9] Bustos, P. (2007), "Multilateral Trade Liberalization, Exports and Technology Upgrading: Evidence on the Impact of MERCOSUR on Argentinean Firms", working paper, Universitat Pompeu Fabra, July.

[10] Chen, N., J. Imbs, and A. Scott (2006), "The dynamics of trade and competition", National Bank of Belgium working paper no. 91.

[11] Clerides, S., S. Lach, and J. Tybout (1998), "Is Learning by Exporting Important? Micro-dynamic Evidence from Colombia, Mexico, and Morocco", Quarterly Journal of Economics 113: 903-947.

[12] Cohen, W., and D. Levinthal (1990), "Absorptive capacity: a new perspective on learning and innovation", Administrative Science Quarterly 35: 128-152.

[13] Combes, P., G. Duranton, L. Gobillon, D. Puga, and S. Roux (2007), "The productivity advantages of large markets: Distinguishing agglomeration from firm selection", October 2007.

[14] De Loecker, J. (2007), "Do Exports Generate Higher Productivity? Evidence from Slovenia", Journal of International Economics 73: 69-98.

[15] Demidova, S. (2006), "Productivity Improvements and Falling Trade Costs: Boon or Bane", Penn State working paper.

[16] Djankov, S., R. La Porta, F. Lopez-de-Silanes, and A. Shleifer (2002), "The Regulation of Entry", Quarterly Journal of Economics 117: 1-37. 
[17] Dunne, T., M. Roberts, and L. Samuelson (1988), "Patterns of firm entry and exit in the U.S. manufacturing industries", RAND Journal of Economics 19: 495-515.

[18] Dunne, T., and M. Roberts (1991), "Variation in Producer Turnover Across US Manufacturing", in P.A. Geroski and J. Schwalbach (eds.), Entry and Market Contestability, Basil Blackwell, 1991.

[19] Falvey, R., D. Greenaway, and Z. Yu (2006), "Extending the Melitz Model to Asymmetric Countries", University of Nottingham research paper 2006/07.

[20] Griffith, R., R. Harrison, and J. van Reenen (2006), "How special is the special relationship?", American Economic Review 96: 1859-1875.

[21] Griliches, Z. (1995), "R\&D and Productivity: Econometric Results and Measurement Issues", Chapter 3 in P. Stoneman (ed.), Handbook of the Economics of Innovation and Technological Change, Basil Blackwell: Oxford.

[22] Griliches, Z. (1979), "Issues in Assessing the Contribution of R\&D to Productivity", Bell Journal of Economics 10: 92-116.

[23] Hallward-Driemeier, M., G. Iarossi, and K. Sokoloff (2002), "Exports and Manufacturing Productivity in East Asia: A Comparative Analysis with Firm-level Data", NBER Working Paper \# 8894.

[24] Horstmann, I., and J. Markusen (1986), "Up the average cost curve: inefficient entry and the new protectionism", Journal of International Economics 20: 225-247. 
[25] Keller, W. (2004), "International Technology Diffusion", Journal of Economic Literature XLII: 752-782.

[26] Keller, W. (2002), "Trade and the Transmission of Technology", Journal of Economic Growth 7: 5-24.

[27] Melitz, M. (2003), "The Impact of Trade on Intra-Industry Reallocations and Aggregate Industry Productivity", Econometrica 71: 1695-1725.

[28] Melitz, M., and G. Ottaviano (2008), "Market Size, Trade, and Productivity", Review of Economic Studies 75: 295-316.

[29] Nicita, A., and M. Olarreaga (2006), "Trade, Production, and Protection, 1976-2004", World Bank Economic Review 21(1).

[30] OECD (2008a), Structural Analysis (STAN) Database, OECD, Paris.

[31] OECD (2008b), Analytical Business Expenditure in Research and Development (ANBERD) Database, OECD, Paris.

[32] OECD (2008c), Bilateral Trade Database (BTD), OECD, Paris.

[33] Pavcnik, N. (2002), "Trade Liberalization, Exit, and Productivity Improvements: Evidence from Chilean Plants", Review of Economic Studies 69: 245-276.

[34] Tybout, J. (2003), "Plant- and Firm-Level Evidence on the 'New' Trade Theories", in Handbook of International Trade, Choi and Harrigan (eds.), Oxford: Basil-Blackwell. 
[35] van Ark, B., et al. (2005), Groningen Growth \& Development Database, Groningen, The Netherlands, http://www.ggdc.net/.

[36] van Biesebroeck, J (2005), "Exporting Raises Productivity in sub-Saharan African Manufacturing Firms", Journal of International Economics 67: 373-391.

[37] van Biesebroeck, J. (2004), "Robustness of Productivity Estimates", NBER Working Paper \# 10303.

[38] Verhoogen, E. (2007), "Trade, Quality Upgrading and Wage Inequality in the Mexican Manufacturing Sector", working paper, Columbia University.

[39] Windmeijer, F. (2005), "A finite sample correction for the variance of linear efficient two-step GMM estimators", Journal of Econometrics 126: 25-51. 
Table 1: Summary statistics for key variables

\begin{tabular}{lccc} 
Variable & Obs & Mean & Stdev \\
\hline & & & \\
TFP & 9,659 & 2.36 & 0.72 \\
US Imports & 10,098 & 11.54 & 1.98 \\
US R\&D & 10,176 & 9.00 & 1.54 \\
US Imports x US R\&D & 9,738 & 105.33 & 30.23 \\
Domestic R\&D & 9,525 & 5.38 & 2.28 \\
Japan R\&D & 10,560 & 7.48 & 2.45 \\
Germany R\&D & 10,432 & 6.76 & 2.58 \\
Av. firm size & 5,433 & 8.77 & 1.44 \\
\hline
\end{tabular}

All variables in logarithms 
Table 2: Sample dynamics

\begin{tabular}{|c|c|c|c|c|c|c|c|}
\hline \multirow[b]{2}{*}{ Variable } & \multicolumn{3}{|c|}{1973 - 1987} & \multicolumn{3}{|c|}{1988 - 2002} & \multirow{2}{*}{$\begin{array}{l}\text { Growth } \\
\text { of Mean }\end{array}$} \\
\hline & Obs & Mean & Stdev & Obs & Mean & Stdev & \\
\hline TFP & 4916 & 2.11 & 0.74 & 4743 & 2.62 & 0.61 & 0.51 \\
\hline Domestic R\&D & 4759 & 4.95 & 2.38 & 4766 & 5.81 & 2.09 & 0.86 \\
\hline US R\&D & 5248 & 8.70 & 1.56 & 4928 & 9.33 & 1.45 & 0.63 \\
\hline US Imports & 5280 & 10.99 & 1.91 & 4818 & 12.14 & 1.88 & 1.16 \\
\hline Japan R\&D & 5632 & 6.91 & 2.30 & 4928 & 8.14 & 2.46 & 1.22 \\
\hline Germany R\&D & 5632 & 6.28 & 2.62 & 4800 & 7.33 & 2.41 & 1.05 \\
\hline Av. Firm size & 2339 & 8.48 & 1.37 & 3094 & 9.00 & 1.44 & 0.52 \\
\hline
\end{tabular}

All variables in logarithms 
Table 3: Productivity across countries

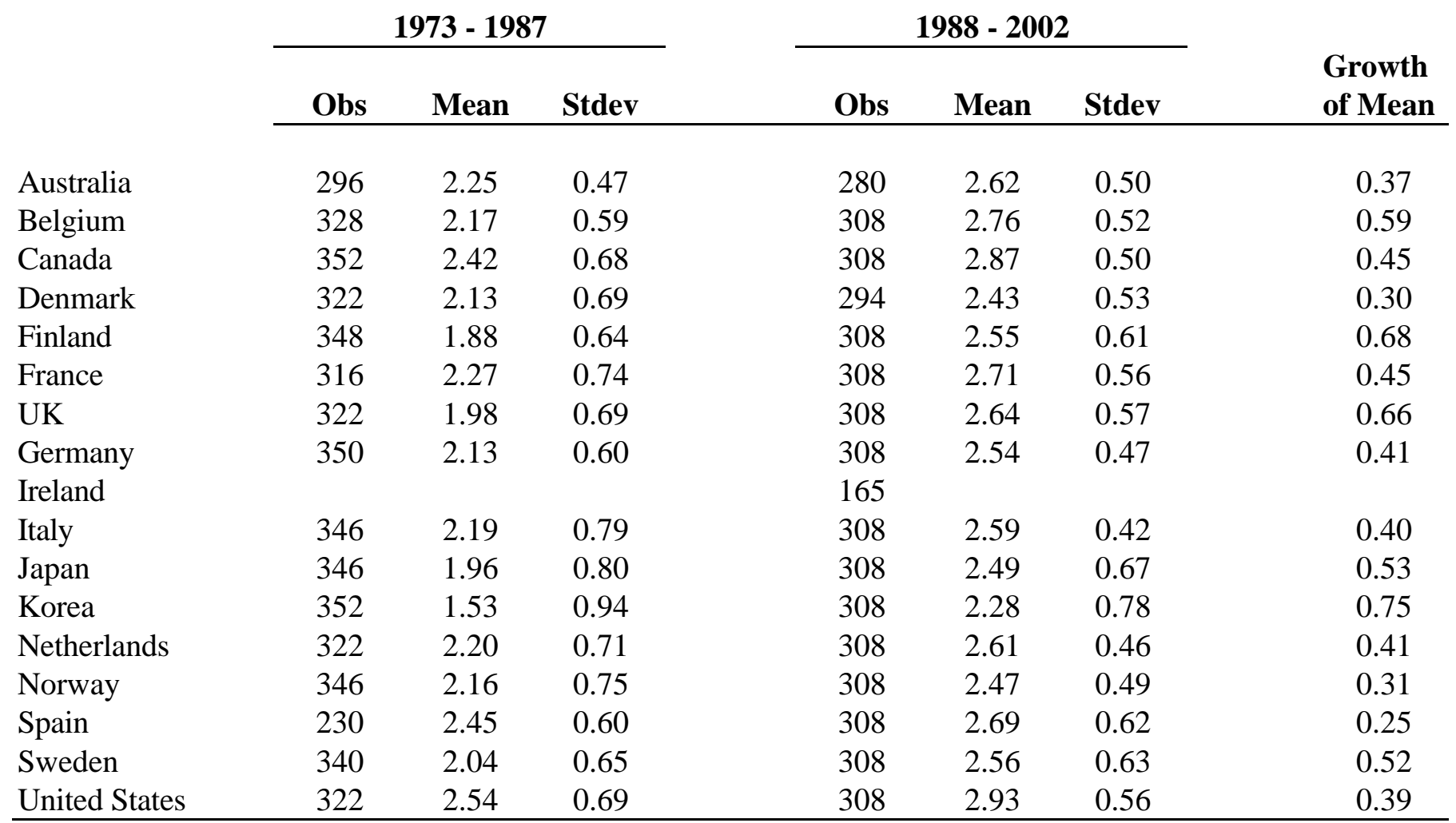

Table 4: R\&D across countries

\begin{tabular}{|c|c|c|c|c|c|c|c|}
\hline & \multicolumn{3}{|c|}{1973 - 1987} & \multicolumn{3}{|c|}{1988 - 2002} & \multirow{2}{*}{$\begin{array}{l}\text { Growth } \\
\text { of Mean }\end{array}$} \\
\hline & Obs & Mean & Stdev & Obs & Mean & Stdev & \\
\hline Australia & 352 & 4.15 & 1.81 & 308 & 5.29 & 1.14 & 1.14 \\
\hline Belgium & 22 & & & 308 & 5.17 & 1.62 & \\
\hline Canada & 352 & 5.14 & 1.86 & 308 & 5.94 & 1.72 & 0.81 \\
\hline Denmark & 352 & 3.32 & 2.17 & 308 & 4.01 & 2.13 & 0.69 \\
\hline Finland & 352 & 3.41 & 1.65 & 308 & 4.93 & 1.18 & 1.52 \\
\hline France & 352 & 6.51 & 1.72 & 308 & 7.35 & 1.53 & 0.84 \\
\hline UK & 352 & 6.86 & 1.61 & 308 & 7.14 & 1.56 & 0.28 \\
\hline Germany & 352 & 6.70 & 2.12 & 300 & 7.82 & 1.54 & 1.13 \\
\hline Ireland & 198 & & & 308 & 3.17 & 1.86 & \\
\hline Italy & 346 & 5.11 & 2.05 & 308 & 6.31 & 1.62 & 1.19 \\
\hline Japan & 352 & 7.37 & 1.51 & 308 & 8.68 & 1.32 & 1.31 \\
\hline Korea & & & & 154 & & & \\
\hline Netherlands & 352 & 4.86 & 2.07 & 308 & 5.58 & 1.70 & 0.72 \\
\hline Norway & 333 & 3.70 & 1.69 & 308 & 4.48 & 1.24 & 0.77 \\
\hline Spain & 352 & 4.25 & 2.12 & 308 & 5.57 & 1.26 & 1.32 \\
\hline Sweden & 340 & 4.94 & 1.84 & 308 & 5.73 & 1.55 & 0.78 \\
\hline United States & 328 & 8.70 & 1.56 & 308 & 9.33 & 1.45 & 0.63 \\
\hline
\end{tabular}


Table 5: The importance of imports from the United States by partner country

\begin{tabular}{|c|c|c|c|c|c|}
\hline & & 1987 & 198 & 2002 & \\
\hline & Obs & $\begin{array}{l}\text { Import } \\
\text { Share* }\end{array}$ & Obs & $\begin{array}{l}\text { Import } \\
\text { Share* }\end{array}$ & Change \\
\hline Australia & 352 & 0.11 & 308 & 0.15 & 0.04 \\
\hline Belgium & 352 & 0.08 & 308 & 0.12 & 0.04 \\
\hline Canada & 352 & 0.47 & 308 & 0.73 & 0.26 \\
\hline Denmark & 346 & 0.03 & 308 & 0.04 & 0.01 \\
\hline Finland & 352 & 0.03 & 308 & 0.04 & 0.01 \\
\hline France & 352 & 0.03 & 308 & 0.03 & 0.01 \\
\hline UK & 352 & 0.15 & 308 & 0.08 & -0.07 \\
\hline Germany & 352 & 0.02 & 308 & 0.03 & 0.01 \\
\hline Ireland & 240 & 0.13 & 294 & 0.15 & 0.01 \\
\hline Italy & 352 & 0.05 & 308 & 0.03 & -0.01 \\
\hline Japan & 352 & 0.02 & 308 & 0.04 & 0.02 \\
\hline Korea & & & 198 & 0.09 & \\
\hline Netherlands & 352 & 0.05 & 308 & 0.11 & 0.06 \\
\hline Norway & 352 & 0.06 & 308 & 0.09 & 0.02 \\
\hline Spain & 322 & 0.04 & 308 & 0.04 & -0.01 \\
\hline Sweden & 352 & 0.07 & 306 & 0.05 & -0.02 \\
\hline
\end{tabular}

*Median ratio of imports from US to domestic value added across industries 
Table 6: US R\&D by industry*

\begin{tabular}{|c|c|c|c|c|c|c|c|}
\hline & & $73-19$ & & & $88-20$ & & \\
\hline & Obs & Mean & Stdev & Obs & Mean & Stdev & of Mean \\
\hline Food products & 256 & 8.68 & 0.19 & 224 & 9.11 & 0.03 & 0.43 \\
\hline Textiles & 256 & 6.73 & 0.22 & 224 & 7.54 & 0.17 & 0.80 \\
\hline Wood products & 256 & 7.94 & 0.23 & 224 & 7.22 & 0.19 & -0.72 \\
\hline Paper products & 256 & 8.54 & 0.23 & 224 & 9.14 & 0.23 & 0.60 \\
\hline Petroleum products & 256 & 9.41 & 0.13 & 224 & 9.44 & 0.13 & 0.03 \\
\hline Chemicals & 256 & 10.16 & 0.27 & 224 & 10.82 & 0.07 & 0.66 \\
\hline Pharmaceuticals & 256 & 9.87 & 0.24 & 224 & 10.79 & 0.25 & 0.92 \\
\hline Rubber \& plastics & 256 & 8.23 & 0.13 & 224 & 8.82 & 0.25 & 0.59 \\
\hline Non-metallic mineral prod. & 256 & 8.19 & 0.18 & 224 & 8.43 & 0.09 & 0.24 \\
\hline Iron and steel & 256 & 8.05 & 0.13 & 224 & 7.83 & 0.10 & -0.21 \\
\hline Non-ferrous metals & 256 & 8.05 & 0.04 & 224 & 8.05 & 0.07 & 0.00 \\
\hline Metal products & 256 & 8.39 & 0.15 & 224 & 8.86 & 0.15 & 0.46 \\
\hline Machinery and eq. & 160 & 9.44 & 0.32 & 224 & 10.06 & 0.20 & 0.62 \\
\hline Computers & 256 & 5.29 & 1.64 & 224 & 10.39 & 1.40 & 5.10 \\
\hline Elect. Machinery & 160 & 9.47 & 0.31 & 224 & 9.78 & 0.20 & 0.31 \\
\hline Communication eq. & 160 & 10.24 & 0.08 & 224 & 11.25 & 1.01 & 1.01 \\
\hline Instruments & 256 & 10.06 & 0.25 & 224 & 10.91 & 0.27 & 0.85 \\
\hline Motor vehicles & 256 & 10.87 & 0.12 & 224 & 11.33 & 0.08 & 0.47 \\
\hline Ships & 160 & 8.52 & 0.37 & 224 & 7.42 & 0.23 & -1.10 \\
\hline Aircraft & 256 & 11.94 & 0.08 & 224 & 11.86 & 0.18 & -0.08 \\
\hline Railroad equipment & 256 & 6.85 & 0.65 & 224 & 8.13 & 0.15 & 1.29 \\
\hline Other manufacturing & 256 & 7.45 & 0.58 & 224 & 7.99 & 0.12 & 0.54 \\
\hline
\end{tabular}

* $\log$ of U.S. R\&D stock 
Table 7: The importance of US imports by industry

\begin{tabular}{|c|c|c|c|c|c|}
\hline & 197 & 1987 & 198 & 2002 & \\
\hline & Obs & $\begin{array}{l}\text { Import } \\
\text { Share* }\end{array}$ & Obs & $\begin{array}{l}\text { Import } \\
\text { Share* }\end{array}$ & Change \\
\hline Food products & 239 & 0.04 & 219 & 0.03 & -0.01 \\
\hline Textiles & 239 & 0.03 & 219 & 0.04 & 0.01 \\
\hline Wood products & 239 & 0.05 & 219 & 0.05 & 0.00 \\
\hline Paper products & 239 & 0.03 & 219 & 0.03 & 0.01 \\
\hline Petroleum products & 234 & 0.08 & 219 & 0.07 & -0.01 \\
\hline Chemicals & 234 & 0.14 & 219 & 0.13 & -0.02 \\
\hline Pharmaceuticals & 234 & 0.05 & 219 & 0.09 & 0.04 \\
\hline Rubber \& plastics & 234 & 0.03 & 219 & 0.05 & 0.02 \\
\hline Non-metallic mineral prod. & 239 & 0.01 & 219 & 0.02 & 0.00 \\
\hline Iron and steel & 234 & 0.01 & 219 & 0.01 & 0.00 \\
\hline Non-ferrous metals & 234 & 0.10 & 219 & 0.09 & -0.01 \\
\hline Metal products & 234 & 0.04 & 219 & 0.02 & -0.02 \\
\hline Machinery and eq. & 229 & 0.09 & 219 & 0.12 & 0.02 \\
\hline Computers & 229 & 1.03 & 219 & 0.99 & -0.05 \\
\hline Elect. Machinery & 229 & 0.09 & 219 & 0.12 & 0.02 \\
\hline Communication eq. & 229 & 0.17 & 217 & 0.24 & 0.07 \\
\hline Instruments & 234 & 0.36 & 219 & 0.36 & 0.00 \\
\hline Motor vehicles & 234 & 0.05 & 219 & 0.06 & 0.00 \\
\hline Ships & 234 & 0.02 & 219 & 0.03 & 0.01 \\
\hline Aircraft & 213 & 0.88 & 205 & 1.13 & 0.25 \\
\hline Railroad equipment & 229 & 0.02 & 219 & 0.06 & 0.05 \\
\hline Other manufacturing & 239 & 0.02 & 219 & 0.04 & 0.02 \\
\hline
\end{tabular}

*Median ratio of imports from US to domestic value added across countries 
Table 8: Technology Transfer and Selection - Fixed Effects Results

(1)

US R\&D

US Imports

US Imports x US R\&D

Domestic R\&D

0.110

$(0.011)$

0.190

$(0.013)$

0.113

$(0.011)$
(4)

$-0.116$

$(0.035)$
0.203

(0.017)

(0.015)

(0.017)

0.067

(0.011)

0.140

0.065

(0.011)

(0.013)

8169

7902

0.719

0.685

0.718

7902

\# of obs

Rsq

Elasticity US R\&D

(5th\%, 95th\%)

Elasticity US Imports

(5th\%, 95th\%)

JPN R\&D

Fixed effect regressions; dependent variable: log total factor productivity

All regressions include fixed effects at the country $\mathrm{x}$ industry level and for each year Robust standard errors in parentheses
0.031

$(0.003)$

0.101

$(0.010)$

0.178

$(0.016)$

7902

0.728

$$
0.25
$$

$(0.14,0.34)$

$-0.02$

$(-0.09,0.06)$ 
Table 9: Technology Transfer and Selection - System IV GMM Results

(1)

US R\&D

US Imports

$-0.014$

(0.023)

US Imports x US R\&D

0.336

(0.048)

(2)

$\begin{array}{cc}0.336 & 0.058 \\ (0.048) & (0.098)\end{array}$

$-0.201$

(0.065)

0.022

(0.007)

Domestic R\&D

0.061

(0.020)

0.056

(0.019)

JPN R\&D

0.121

(0.043)

0.116

(0.039)

GER R\&D

0.070
$(0.023)$

0.078

(0.022)

\# of obs

6915

6915

AR(1) test

$-1.78$

$-2.01$

[p-value]

[0.08]

[0.04]

AR(2) test

1.47

1.39

[p-value]

[0.14]

[0.17]

Hansen OverID J

[p-value]

Elasticity US R\&D

(5th \%, 95th \%)

$$
\begin{gathered}
4.16 \\
{[0.655]}
\end{gathered}
$$

[0.736]

Elasticity US Imports

(5th \%, 95th \%)

$(0.19,0.33)$

$-0.01$

$(-0.20,0.06)$

Dependent variable: log total factor productivity

All regressions include fixed effects for year, country, and industry Robust Windmeijer (2005)-corrected standard errors in parentheses Instruments: Domestic R\&D lags4-6, US imports lags 2-6,

Imports x US R\&D lag 2, US R\&D lag 2; other IVs contemporaneous 
Table 10: Productivity, size, and the number of firms

\begin{tabular}{|c|c|c|c|c|c|c|}
\hline & $\begin{array}{c}\text { TFP } \\
(1)\end{array}$ & $\begin{array}{c}\text { Firm Size } \\
(2) \\
\end{array}$ & $\begin{array}{c}\text { No. Firms } \\
(3) \\
\end{array}$ & $\begin{array}{l}\text { TFP } \\
(4)\end{array}$ & $\begin{array}{c}\text { Firm Size } \\
(\mathbf{5}) \\
\end{array}$ & $\begin{array}{c}\text { No. Firms } \\
(6) \\
\end{array}$ \\
\hline US R\&D & $\begin{array}{c}0.175 \\
(0.023)\end{array}$ & $\begin{array}{c}0.444 \\
(0.039)\end{array}$ & $\begin{array}{l}-0.156 \\
(0.027)\end{array}$ & $\begin{array}{l}-0.517 \\
(0.053)\end{array}$ & $\begin{array}{l}-0.743 \\
(0.092)\end{array}$ & $\begin{array}{c}0.103 \\
(0.063)\end{array}$ \\
\hline US Imports & $\begin{array}{l}-0.008 \\
(0.011)\end{array}$ & $\begin{array}{c}0.031 \\
(0.020)\end{array}$ & $\begin{array}{c}0.002 \\
(0.016)\end{array}$ & $\begin{array}{l}-0.514 \\
(0.040)\end{array}$ & $\begin{array}{l}-0.842 \\
(0.067)\end{array}$ & $\begin{array}{c}0.193 \\
(0.046)\end{array}$ \\
\hline US Imports $x$ US R\&D & & & & $\begin{array}{c}0.059 \\
(0.005)\end{array}$ & $\begin{array}{c}0.101 \\
(0.008)\end{array}$ & $\begin{array}{l}-0.022 \\
(0.005)\end{array}$ \\
\hline Domestic R\&D & $\begin{array}{c}0.051 \\
(0.014)\end{array}$ & $\begin{array}{c}0.099 \\
(0.026)\end{array}$ & $\begin{array}{c}0.072 \\
(0.020)\end{array}$ & $\begin{array}{c}0.019 \\
(0.012)\end{array}$ & $\begin{array}{c}0.050 \\
(0.025)\end{array}$ & $\begin{array}{c}0.083 \\
(0.020)\end{array}$ \\
\hline GER R\&D & $\begin{array}{c}0.183 \\
(0.022)\end{array}$ & $\begin{array}{c}0.220 \\
(0.040)\end{array}$ & $\begin{array}{l}-0.064 \\
(0.027)\end{array}$ & $\begin{array}{c}0.197 \\
(0.020)\end{array}$ & $\begin{array}{c}0.244 \\
(0.036)\end{array}$ & $\begin{array}{l}-0.070 \\
(0.027)\end{array}$ \\
\hline \# of obs & 4844 & 5082 & 5092 & 4844 & 5082 & 5092 \\
\hline Rsq & 0.639 & 0.300 & 0.245 & 0.670 & 0.334 & 0.248 \\
\hline $\begin{array}{l}\text { Elasticity US R\&D } \\
(5 \text { th } \%, 95 \text { th } \%)\end{array}$ & & & & $\begin{array}{c}0.245 \\
(-0.035,0.350)\end{array}$ & $\begin{array}{c}0.447 \\
(0.096,0.766)\end{array}$ & $\begin{array}{c}-0.156 \\
(-0.226,-0.080)\end{array}$ \\
\hline $\begin{array}{l}\text { Elasticity US Imports } \\
(5 \text { th } \%, 95 \text { th } \%)\end{array}$ & & & & $\begin{array}{c}-0.032 \\
(-0.102,0.167)\end{array}$ & $\begin{array}{c}0.070 \\
(-0.124,0.347)\end{array}$ & $\begin{array}{c}-0.006 \\
(-0.066,0.037)\end{array}$ \\
\hline
\end{tabular}


Table 11: Firm dynamics and selection

Country-specific turnover data

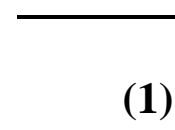

(2)

(3)

(4)

(5)

Domestic R\&D

U.S. R\&D

U.S. Imports

Dom R\&D x Low Turnover

U.S. R\&D x Low Turnover

$\begin{array}{cccc}0.113 & 0.114 & 0.105 & 0.109 \\ (0.011) & (0.012) & (0.012) & (0.024)\end{array}$

$\begin{array}{cccc}0.247 & 0.247 & 0.265 & 0.265 \\ (0.015) & (0.015) & (0.017) & (0.017)\end{array}$

$\begin{array}{llll}-0.037 & -0.037 & -0.036 & -0.048\end{array}$

(0.008)

(0.008)

(0.008)

(0.009)

\subsection{2}

0.024

(0.017)

(0.013)

(0.016)

$-0.094$

$-0.108$

$-0.146$

(0.025)

$(0.027)$

(0.031)

\section{U.S. Imp x Low Turnover}

Rsq

$$
0.719
$$

0.719

0.720

0.048

$(0.013)$

0.049

(0.016)

0.721 
Table 12: Entry regulation, turnover, and selection

\begin{tabular}{|c|c|c|c|c|}
\hline & (1) & $(2)$ & (3) & (4) \\
\hline U.S. R\&D & $\begin{array}{c}0.246 \\
(0.015)\end{array}$ & $\begin{array}{c}0.24 \\
(0.015)\end{array}$ & $\begin{array}{c}0.265 \\
(0.017)\end{array}$ & $\begin{array}{c}0.26 \\
(0.017)\end{array}$ \\
\hline U.S. Imports & $\begin{array}{c}-0.036 \\
(0.008)\end{array}$ & $\begin{array}{c}-0.036 \\
(0.008)\end{array}$ & $\begin{array}{l}-0.048 \\
(0.009)\end{array}$ & $\begin{array}{l}-0.058 \\
(0.010)\end{array}$ \\
\hline Domestic R\&D & $\begin{array}{c}0.107 \\
(0.011)\end{array}$ & $\begin{array}{c}0.11 \\
(0.011)\end{array}$ & $\begin{array}{c}0.113 \\
(0.011)\end{array}$ & $\begin{array}{c}0.111 \\
(0.013)\end{array}$ \\
\hline U.S. R\&D x High Regulation & & $\begin{array}{c}0.018 \\
(0.026)\end{array}$ & $\begin{array}{c}0.015 \\
(0.026)\end{array}$ & $\begin{array}{c}0.012 \\
(0.026)\end{array}$ \\
\hline U.S. Imp x High Regulation & & & $\begin{array}{c}0.037 \\
(0.014)\end{array}$ & $\begin{array}{c}0.039 \\
(0.014)\end{array}$ \\
\hline Domestic R\&D x High Regulation & $\begin{array}{c}0.015 \\
(0.015)\end{array}$ & $\begin{array}{c}0.004 \\
(0.018)\end{array}$ & $\begin{array}{c}-0.009 \\
(0.019)\end{array}$ & $\begin{array}{l}-0.014 \\
(0.020)\end{array}$ \\
\hline U.S. R\&D x Low Turnover & & & & $\begin{array}{l}-0.109 \\
(0.027)\end{array}$ \\
\hline U.S. Imp x Low Turnover & & & & $\begin{array}{c}0.047 \\
(0.013)\end{array}$ \\
\hline Domestic R\&D x Low Turnover & & & & $\begin{array}{c}0.026 \\
(0.018)\end{array}$ \\
\hline Rsq & 0.719 & 0.719 & 0.720 & 0.721 \\
\hline
\end{tabular}

Fixed effects regression; dependent variable: $\log$ TFP

All specifications include country $\mathrm{x}$ industry fixed effects, year fixed effects, as well as JPN R\&D and GER R\&D (coefficients not reported)

Robust s.e. in parentheses; number of observations: 7,902 
Table 13: Selection over time

Time horizon in years

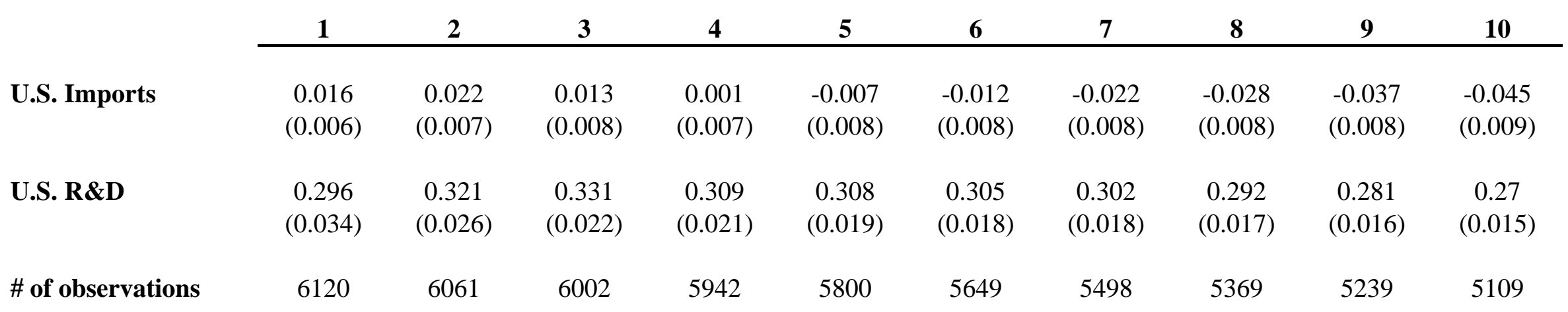

Time-differenced OLS regressions; dependent variable: change in log TFP; estimations exploit variation from changes over one year to changes over ten years All regressions include the change in log domestic R\&D, JPN, and GER R\&D, and time fixed effects

Robust standard errors in parentheses 
Figure 1: Entry barriers across countries

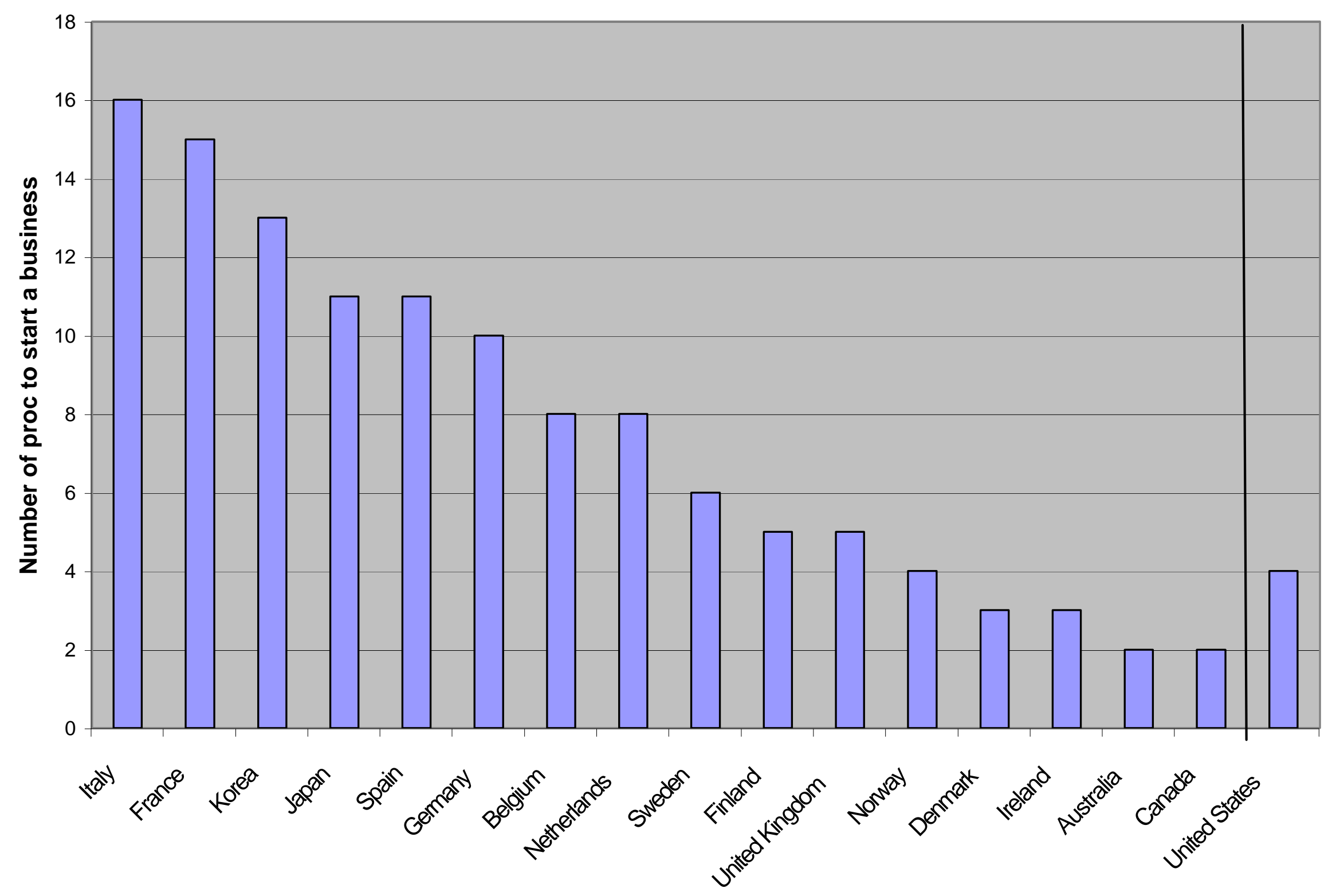


Figure 2: Gross turnover by country and by industry

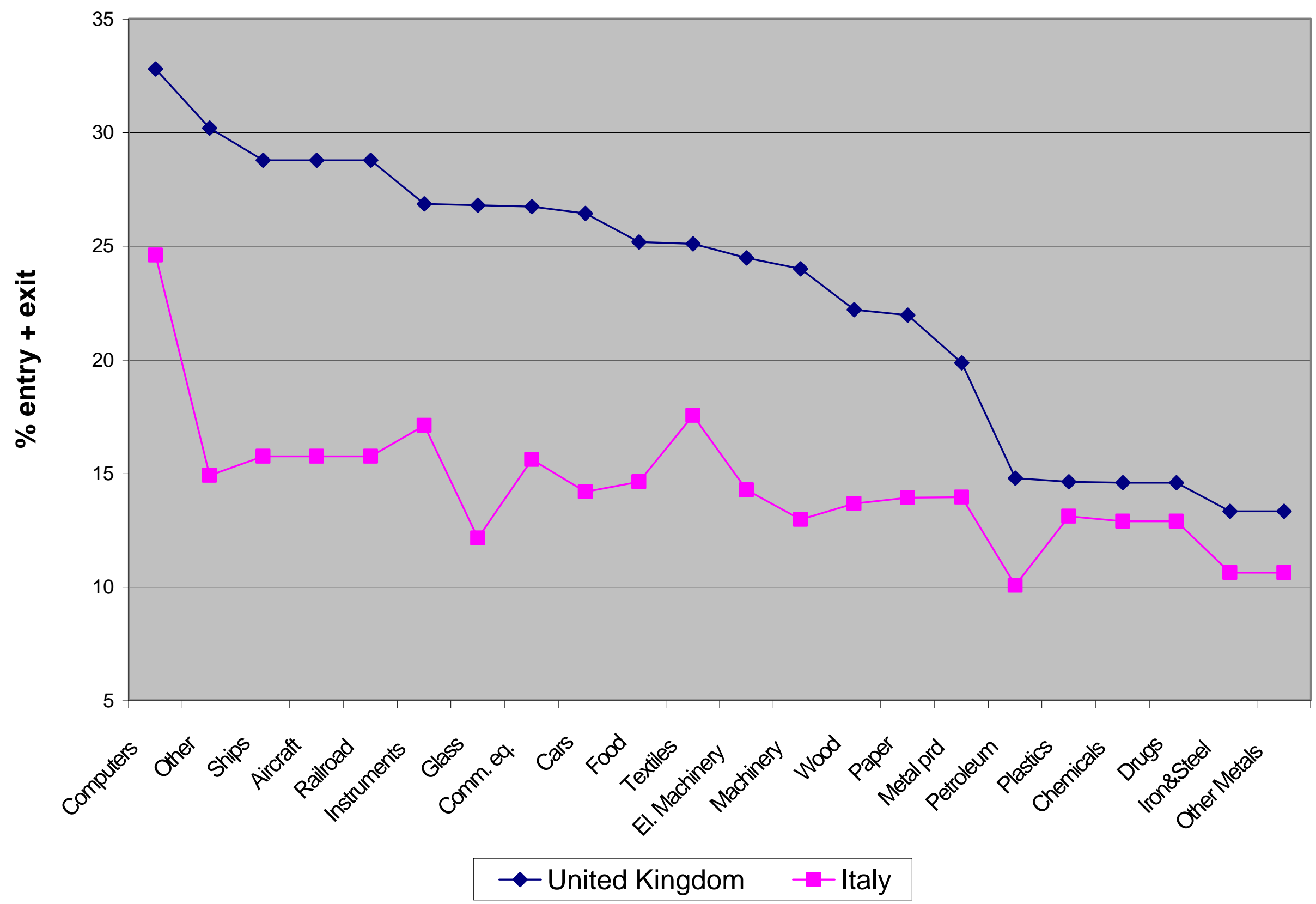


Figure 3: The productivity impact of US R\&D and US imports over different time horizons

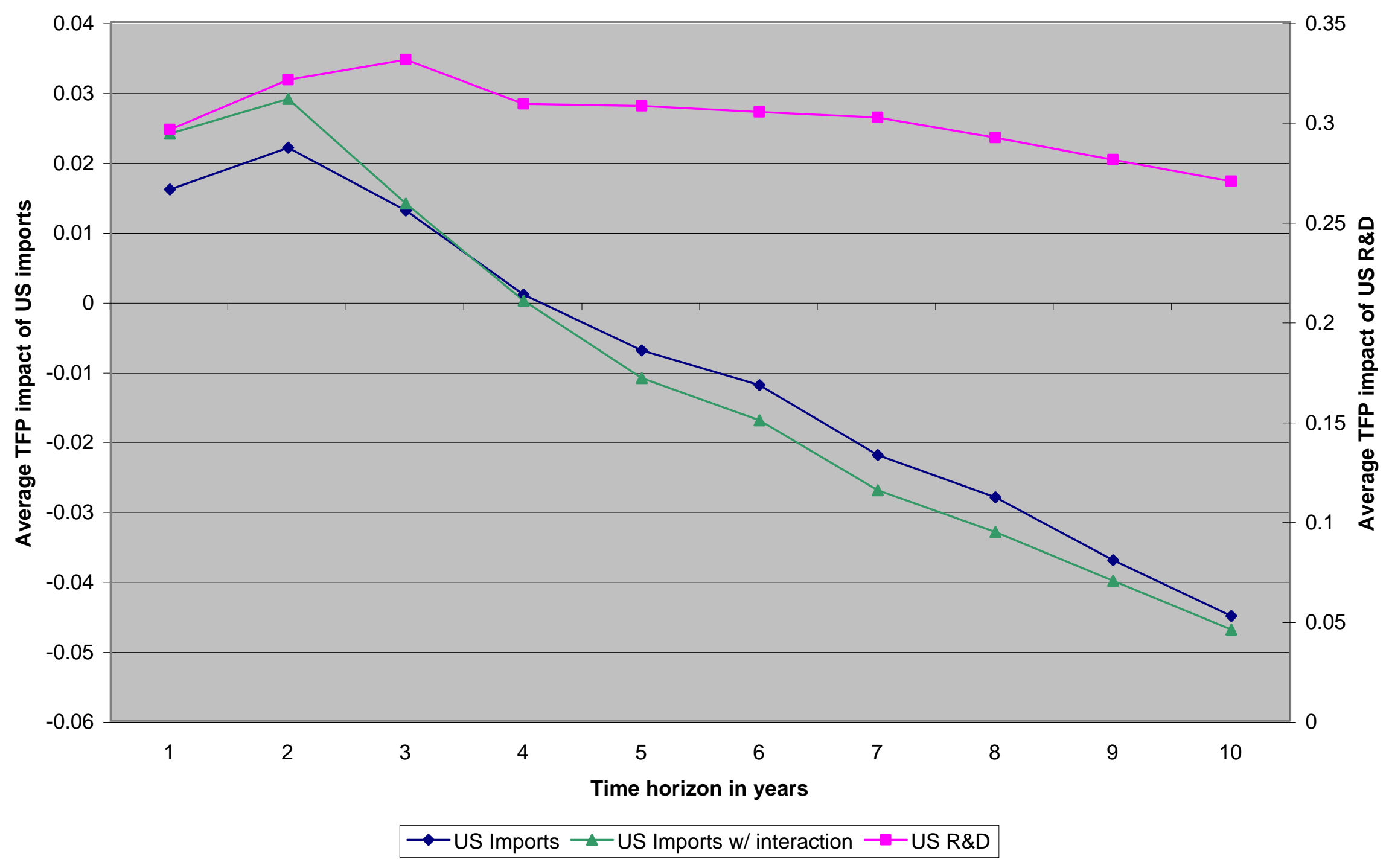


Table A1: The matching of industries for the firm size variable

\section{Classification of this study}

$\begin{array}{ll}1 & \text { Food, beverages, and tobacco } \\ 2 & \text { Textiles, apparel, footwear } \\ 3 & \text { Wood products, furniture } \\ 4 & \text { Paper and printing } \\ 5 & \text { Petroleum products } \\ 6 & \text { Chemicals } \\ 7 & \text { Pharmaceuticals } \\ 8 & \text { Rubber \& plastics } \\ 9 & \text { Non-metallic mineral prod. } \\ 10 & \text { Iron and steel } \\ 11 & \text { Non-ferrous metals } \\ 12 & \text { Metal products } \\ 13 & \text { Machinery and eq. } \\ 14 & \text { Computers } \\ 15 & \text { Elect. Machinery } \\ 16 & \text { Communication eq. } \\ 17 & \text { Instruments } \\ 18 & \text { Motor vehicles } \\ 19 & \text { Ships } \\ 20 & \text { Aircraft } \\ 21 & \text { Railroad equipment } \\ 22 & \text { Other manufacturing } \\ & \end{array}$

\section{ISIC 3 digit classification employed by UNIDO}

\begin{tabular}{|c|c|c|c|c|c|}
\hline 311 & Food products & 313 & Beverages & 314 & Tobacco \\
\hline 321 & Textiles & 322 & Apparel & 323 & Leather products \\
\hline 331 & Wood products & 332 & Furniture & & \\
\hline 341 & Paper & 342 & Printing, publishing & & \\
\hline 353 & Petroleum refineries & 354 & Petroleum products & & \\
\hline 351 & Industrial chemicals & & & & \\
\hline 352 & Other chemicals & & & & \\
\hline 355 & Rubber products & 356 & Plastic products & & \\
\hline 361 & Pottery, china & 362 & Glass & 369 & Other n-met. min. \\
\hline 371 & Iron and steel & & & & \\
\hline 372 & Non-ferrous metals & & & & \\
\hline 381 & Metal products & & & & \\
\hline 382 & Machinery* & & & & \\
\hline 383 & Electrical machinery** & & & & \\
\hline 385 & Instruments & & & & \\
\hline 384 & Transportation equipment ${ }^{* * *}$ & & & & \\
\hline
\end{tabular}

Notes:

Information on the number of firms is form Nicita/Olarreaga (2006), based on UNIDO data; it is generally available for the years 1981-2002

Major exceptions are France, where 23\% of all possible observations are available, as well as Ireland and Germany (about $45 \%$ ).

* These values are applied to both industries 13 and 14

** These values are applied to both industries 15 and 16

*** These values are applied to industries 18, 19, 20, and 21 
Table A2: Productivity and Imports from the United States, Japan, and Germany

\begin{tabular}{|c|c|c|c|}
\hline & $\begin{array}{c}\text { Imports } \\
\text { from the US } \\
\text { (Foreign = US) }\end{array}$ & $\begin{array}{c}\text { Imports } \\
\text { from Japan } \\
(\text { Foreign = JPN) }\end{array}$ & $\begin{array}{c}\text { Imports } \\
\text { from Germany } \\
\text { (Foreign = GER) }\end{array}$ \\
\hline Foreign R\&D & $\begin{array}{l}-0.116 \\
(0.035)\end{array}$ & $\begin{array}{c}0.177 \\
(0.027)\end{array}$ & $\begin{array}{l}-0.040 \\
(0.025)\end{array}$ \\
\hline Foreign Imports & $\begin{array}{l}-0.303 \\
(0.028)\end{array}$ & $\begin{array}{l}-0.135 \\
(0.017)\end{array}$ & $\begin{array}{l}-0.108 \\
(0.020)\end{array}$ \\
\hline Imports $x$ Foreign $R \& D$ & $\begin{array}{c}0.031 \\
(0.003)\end{array}$ & $\begin{array}{c}0.015 \\
(0.002)\end{array}$ & $\begin{array}{c}0.013 \\
(0.003)\end{array}$ \\
\hline Domestic R\&D & $\begin{array}{c}0.101 \\
(0.010)\end{array}$ & $\begin{array}{c}0.072 \\
(0.010)\end{array}$ & $\begin{array}{c}0.132 \\
(0.012)\end{array}$ \\
\hline U.S. R\&D & & $\begin{array}{c}0.157 \\
(0.014)\end{array}$ & $\begin{array}{c}0.176 \\
(0.018)\end{array}$ \\
\hline JPN R\&D & $\begin{array}{c}0.178 \\
(0.016)\end{array}$ & & $\begin{array}{c}0.218 \\
(0.019)\end{array}$ \\
\hline GER R\&D & $\begin{array}{c}0.097 \\
(0.011)\end{array}$ & $\begin{array}{c}0.050 \\
(0.011)\end{array}$ & \\
\hline \# of obs & 7902 & 7891 & 7898 \\
\hline Rsq & 0.728 & 0.737 & 0.710 \\
\hline $\begin{array}{l}\text { Elasticity For R\&D } \\
(5 \text { th\%, 95th\%) }\end{array}$ & $\begin{array}{c}0.25 \\
(0.14,0.34)\end{array}$ & $\begin{array}{c}0.33 \\
(0.26,0.39)\end{array}$ & $\begin{array}{c}0.12 \\
(0.08,0.15)\end{array}$ \\
\hline $\begin{array}{l}\text { Elasticity For IMP } \\
(5 \text { th\%, 95th\%) }\end{array}$ & $\begin{array}{c}-0.02 \\
(-0.09,0.06)\end{array}$ & $\begin{array}{c}-0.01 \\
(-0.05,0.02)\end{array}$ & $\begin{array}{c}-0.01 \\
(-0.05,0.02)\end{array}$ \\
\hline
\end{tabular}

Dependent variable: log total factor productivity All regressions include fixed effects at the country $\mathrm{x}$ industry level and for each year Robust standard errors in parentheses 
Table A3: TFP Based on Industry-Specific Factor Shares

Fixed Effects

(1)

US R\&D

US Imports

US Imports x US R\&D

Domestic R\&D

JPN R\&D

GER R\&D

0.098

$(0.011)$

$(0.034)$

$-0.255$

$(0.027)$

0.027

$(0.003)$

0.075

(0.010)

0.170

(0.015)

0.123

(0.038)

0.067

(0.022)

\# of obs

7902

6915

Hansen OverID J

9.38

[p-value]

[0.153]

Dependent variable: log total factor productivity with industry-varying factor shares

Column (1) includes fixed effects for year and country-by-industry

Column (2) has fixed effects for country, year, and industry

Robust standard errors in parentheses; Windmeijer-corrected in column (2)

In column (1), all right hand side variables are lagged by two years

Instruments column (2): Domestic R\&D lags4-6, US imports lags 2-6,

Imports x US R\&D lag 2, US R\&D lag 2; other IVs contemporaneous 